\title{
Performance Appraisal System and Its Practices in Local Private Business Organizations of Bangladesh
}

\author{
*Taskina Ali ${ }^{1}$, Nargis Akter ${ }^{2}$ \\ ${ }^{1}$ School of Business United International University, Dhaka, Bangladesh. \\ 2Department of Business Administration, East West University, Dhaka, Bangladesh \\ *taskina.ali@gmail.com
}

\begin{abstract}
This present paper focuses on the performance appraisal practices of local private organizations in Bangladesh. Here, the researchers found that, almost all the organizations have formal performance evaluation systems. Though there is variation in their methods, frequency of occurrence and parties involved in evaluation system. In terms of method majority (16\%) of the organizations prefer Management by Objective (MBO) method. Concerning the frequency of performance appraisal $69.23 \%$ local organizations evaluate their employees annually. It is also observed that majority of the employees are satisfied with present performance appraisal systems. The researchers also recommend a comparative analysis between the performance appraisal practice of local private business enterprises of Bangladesh and performance appraisal practice of multinational business enterprises.
\end{abstract}

Keywords: Performance management systems, Local private business organizations, performance feedback, Employee efficiency, Employee evaluation.

\section{Introduction}

Evaluation of employees' performance is a common practice in today's business organization. Because there are so many organizations who have tied their rewards programs and other administrative decisions with the employee performance evaluation systems. It has long been recognized that performance appraisal plays pivotal role in organization (Borman, 1979; Landy and Farr, 1980; Saal, Downey and Lahey, 1980). Employee performance appraisal is subjects of great interest in most organizations (Armstrong, 1998; Bratton and Gold, 1999).There are several reasons behind this. First reason is performance appraisal decisions have effects and consequences on worker's compensation and recognition (Bartol and Locke, 2000; Millward et al,. 2000; Perry, 1995). Second important reason is, performance appraisal is important for the development of the strategic human resources, which looks at employees as an organizational tool for an organization to survive in competitive and turbulent situations (Argyris, 1994; Ahmad and Spicer, 2000).

Another important reason is performance appraisal is important as a management tool to assess employees' efficiency in the work place (Armstrong and Baron, 1998).Performance appraisal is defined as 'the systematic evaluation of the individual with respect to his performance on-the-job and his potential for development (Beach, 1995). Performance evaluation method serves a variety of purposes such as providing the basis for making selection decisions, determining salary increases, and providing a vehicle for feedback between supervisors and employees. Performance appraisals are considered to be an important 
tool in US, Japan, Korea, and other developed countries. The multi- faceted purposes of performance appraisals are important because they strongly influence the impact of appraisals on both managers and employees (Milliman, Nathan and Mohrman, 1991). After doing regular performance appraisal process, employer or the superiors should provide timely feedback to the employees. Performance feedback is one of the most important aspects of performance management (Fisher, Schoenfeldt and Shaw, 2008). If they (employees) are not informed about their performance, they can not make the changes in their exhibited behavior. New employees often feel unqualified to judge their own performance and prefer to be told how they are doing and what is expected of them (Hillery and Wexely, 1974).

The private sector in most countries is going through profound restructuring in the face of global economic crisis that forces the sector to become more efficient and effective. Like other developing countries, in Bangladesh local private organizations are the major contributor in the country's economy. Moreover from the agro-based economy, Bangladesh's economy is shifting towards service and manufacture based economy. Today we can see private enterprises are taking initiatives in both the aforementioned sectors. These local organizations are continuously trying to enhance their efficiency. It is needless to mention that organizational efficiency indicates actually the employees' efficiency. In order to ensure employee efficiency any organization must ensure evaluating the performance of employees. In an increasing turbulent and highly competitive global economy, effective human resource management (HRM) practices are essential in developing a skilled workforce (Cascio and Bailey, 1995) and organizational flexibility and fit (Butler, Ferris and Nappier, 1991). Perhaps there is not a more important human resource practices in organizations than performance evaluation. In order to ensure effective evaluation and utilization of performance appraisal, well structured appraisal system is highly required.

The purpose of the research is to focus on the existing performance appraisal systems of local private organization of Bangladesh. For the better understanding the researchers break down the broad objectives into specific objectives:

- To know about the types of performance appraisal methods used by the local private organizations of Bangladesh.

- To measure the degree of overall satisfaction of employees regarding performance appraisals.

- To know about the opinion of employees towards feedback session and performance appraisals.

\section{Literature Review}

Performance appraisal is a formal management system that provides for the evaluation of the quality of an individual's performance in an organization (Yousef, 2000).The term 'performance appraisal' is generally meant the annual interview that takes place between the manager and the employee to discuss the individual's job performance during the previous 12 months and the compilation of action to encourage improved performance (Wilson and Western, 2000). Yong (1996) described it as a periodic evaluation of the output of an individual measured against certain expectations. In the last ten years, there has been an increase in the number of studies which have investigated the characteristics of effective performance appraisal systems. These studies have used questionnaires to assess individuals' reactions to various aspects of the appraisal system (Latham and Wexley, 1981). The basic premise of this research is that employees' opinions regarding the appraisal process are critical to the long-term effectiveness of the system. 
In one study, Landy, Barnes and Murphy (1978) examined employee perceptions of the fairness and accuracy of a performance evaluation system. They found several reliable correlates of these perceptions like: frequent evaluations by supervisors, familiarity with performance levels of the person evaluated, agreement with the subordinate on job duties, and engaging in helping subordinates form plans for eliminating performance weaknesses. Another study conducted by Igen, Petersen, Martin and Boeshen (1981) compared supervisor and subordinate reactions to performance appraisal sessions. They found only moderate agreement between subordinate and supervisors regarding the supervisors' task and interpersonal skills and the nature of subordinates' performance

In Bangladesh, there is a "poor knowledge-base" regarding the practice of performance appraisal of employees in the various local private manufacturing enterprises of Bangladesh (Akhter, 2008). That is why researchers are interested to know what the managers and employees both perceived the existing performance appraisal system and the feedback session of the local private business organizations. The second issue of this study has not been received a great deal of attention i.e., the extent to which feedback or feedback session affects the employees with regards to their job and other organization. One of the primary purposes of formal performance appraisals is to provide clear, performance based feedback to employees (Carroll and Schneier, 1982; Larson, 1984). From the organization's point of view, feedback keeps both its members' behavior directed toward desired goals and stimulates and maintains high levels of effort (Lawler, 1994; Vroom, 1964).From the individual's point of view, feedback satisfies a need for information about the extent to which personal goals are met (Nadler, 1977) as well as a need for social comparison information about one's relative performance (Festinger, 1954). Ilgen et al. (1981); Kluger and De Nisi, (1996) identified feedback potentially can influence future performance. Research has found that although people express a strong desire for feedback (Ashford, 1986), most appreciate positive feedback and tend to dismiss negative feedback (Taylor et al, 1984).

\section{Research Methods}

Sources of Data: Comprehensive research work conducted to achieve the aforesaid objectives of the study. Both primary and secondary data have been used for the purpose of this study. To collect primary data a structured questionnaire was designed in the light of the objectives of the study. Secondary data were collected from available books, journals and websites on performance evaluation practices and feedback session of local private organizations.

Sample size Location (selection of local private business organizations and respondents): The sample of this study was consisted of 65 local private organizations of Bangladesh. From each organization, 1 employer's opinion was taken and 2 employee's opinion was collected. In case of employees, one is from entry level position and one is from mid level position. As result of that, employees sample size was 130. The factual data were collected from the human resource managers and the attitudinal data were collected from the employees. In order to collect data from employees the researchers include mid level managers/executives and junior executives/managers. In order to collect employees' opinions regarding performance appraisal practice, Likert's five point scale was used. The study was conducted in Dhaka city as because Dhaka is the main locus of private organization's headquarters or the main branches. In order to select the private organizations, lists of private companies were taken from Dhaka Stock Exchange (DSE). 
Questionnaire Design: A structured, closed- ended questionnaire was given to respondents for collecting their opinions regarding current performance appraisal practices and the feedback session of evaluation of employees. The respondents were also asked about their gender, total years of education, academic rank, and total years of work experience. In terms of scaling method, a five point Likert Scale 5 for very much satisfactory, 4 for satisfactory, 3 for neither satisfactory nor dissatisfactory, 2 for dissatisfactory and 1 for very much dissatisfactory) has been used.

Data Analysis: The collected data have been edited, coded and analyzed in line with the research objective.

\section{Result and Discussion}

The present study shows that all local private companies operated in Bangladesh practice performance appraisal Though there are wide variations in terms of frequency of conducting performance appraisals, purpose and methods of appraisals but the entire local private organizations practice performance appraisal for their employees. The analysis of the study reveals (Table-1) that various performance appraisal methods are used in the local private organizations. Majority (16\%) of the organizations prefer Management by Objective (MBO) method, the second preference was Essay Appraisal Method (13\%). But Human Resource Accounting (1\%) was least preferred by the local private organizations in Bangladesh.

Table 1: Performance Evaluation Method Used by Local Private Organizations

\begin{tabular}{ll}
\hline Name of Methods & $\begin{array}{l}\text { Use of performance evaluation methods in } \\
\text { local private organizations (\%) }\end{array}$ \\
\hline Essay Appraisal & 13 \\
Paired Comparison & 5 \\
Field Review & 6 \\
Graphic Rating Scale & 6 \\
Management by Objectives & 16 \\
Assessment Centers & 3 \\
Human Resource Accounting & 1 \\
Straight Ranking & 16 \\
Critical Incident Techniques & 4 \\
Checklist & 13 \\
Forced Distribution & 3 \\
360 Degree Feedback appraisal & 6 \\
Behaviorally Anchor Rating Scale & 4 \\
Others & 8 \\
\hline
\end{tabular}

Survey: 2010

The study found that all local private business organizations have formal performance appraisal programs. Table-2 shows that majority (69.23\%) of local private business organizations evaluate their employees annually, $13.85 \%$ evaluate semi-annually, whereas $16.92 \%$ evaluates employees quarterly. Again it is found in the study that though local private business organizations are in strong favor of frequent performance appraisal; it is not frequently practiced by most of the respondents. 
Table 2: Frequency of Performance Appraisal

\begin{tabular}{ll}
\hline Issues & Frequency \\
\hline Annually & $69.23 \%$ \\
Semi- Annually & $13.85 \%$ \\
Quarterly & $16.92 \%$ \\
\hline
\end{tabular}

Table 3: Parties involved in the Performance Appraisal

\begin{tabular}{ll}
\hline Parties Involved & Percentage of Respondents \\
\hline Immediate supervisor & 39.84 \\
Immediate Boss and HR head & 32.52 \\
Immediate boss, HR head and Employees & 27.64 \\
\hline
\end{tabular}

In this study, 39.84\% respondents said that their immediate supervisor evaluates their performance, $32.52 \%$ respondents said that their immediate boss and HR head evaluate employee's performance, and 27.64\% respondents said all three parties (immediate boss, HR head and employees) are involved in the performance evaluation process. Table- 4 shows that although a very few percentage of employees $(21.14 \%)$ of the local private business organizations opined that performance evaluation methods of their organizations are very much satisfactory, significant percentage $(48.78 \%$ ) of the employees considered their performance appraisal methods "satisfactory".

Table-4 Employees' Opinion regarding Performance Appraisal Practices

\begin{tabular}{|c|c|c|c|c|c|c|}
\hline \multirow[t]{2}{*}{$\mathrm{S} / \mathrm{N}$} & \multirow[t]{2}{*}{ Statements } & \multicolumn{5}{|c|}{ Options } \\
\hline & & $\begin{array}{c}\text { Very much } \\
\text { Satisf }\end{array}$ & Satisf & $\begin{array}{c}\text { Neither satisf } \\
\text { nor dissatisf }\end{array}$ & Dissatisf & $\begin{array}{c}\text { Very much } \\
\text { dissatisf }\end{array}$ \\
\hline 1. & $\begin{array}{l}\text { Employees' opinion } \\
\text { about the Performance } \\
\text { evaluation method }\end{array}$ & 21.14 & 48.78 & 22.76 & 6.50 & 0.81 \\
\hline 2. & $\begin{array}{l}\text { Employees' } \quad \text { Feedback } \\
\text { session }\end{array}$ & 16.26 & 42.28 & 26.83 & 8.94 & 5.69 \\
\hline 3. & $\begin{array}{l}\text { Use of performance } \\
\text { evaluation record by the } \\
\text { organization }\end{array}$ & 14.63 & 36.51 & 31.89 & 11.38 & 6.50 \\
\hline
\end{tabular}

The researchers found the same picture regarding the employees' opinions towards the feedback session and use of performance evaluation record by the organization. It is clear from table 4 that although only $16.26 \%$ of the employees are very much satisfied regarding the employees' feedback session, a considerable percent $(42.28 \%)$ of the employees are satisfied with the feedback session. The data which the study found about the employees' opinions regarding the feedback session and use of performance evaluation record by the organization is that although only $16.26 \%$ of the employees are very much satisfied with the feed back session, a considerable percent(42.28\%) of them are satisfied with the feedback session and although only $14.63 \%$ of the employees are very much satisfied with the use of performance evaluation record by the organizations, a considerable percent of them are satisfied with the use of performance evaluation recode by the organization. 


\section{Conclusion and Recommendations}

Performance appraisal is used in many organizations as an instrument for facilitating and enhancing performance management of the organization. It is considered as a vital instrument to establish the accountability of the employees. In many organizations, performance appraisal results are used to determine the efficiency level of employees, to identify the better employees and these results are used directly or indirectly to make administrative decisions like- promotion, merit increment, bonuses and also punishment. Local private organizations in Bangladesh are found to practice performance appraisal But there are wide variations in methods, frequency and also the parties involved. Moreover, employees seem very satisfied with the present performance appraisal system. In all the sampled local private organizations, most of them used single method to evaluate employee performance but very few also use multiple appraisal methods. Findings of the present study can help the industry to develop an effective performance appraisal system and also a feedback session can be practiced by the organizations so that overall performance of the organization can be accelerated. A well thought -out performance appraisal system will definitely improve overall performance of the organizations.

Performance appraisal is used in many organizations as an instrument for facilitating and enhancing performance management of the organization. It is considered as a vital instrument to establish the accountability of the employees. Local private business organizations of Bangladesh are found to practice performance appraisal. But there are wide variations in methods, frequency and also the parties involved In all the sample local private business organizations, most of them used single method to evaluate employee performance but very few also use multiple appraisal methods. Moreover, although a very few percentage of employees are very much satisfied with the performance evaluations method, feedback session and use of performance evaluation record by the organization, a considerable percentage of them are satisfied with these. The findings of the present study can help to conduct a comparative analysis between the performance appraisal practice of local private business organizations of Bangladesh and performance appraisal practice of multinational business organizations. The present study also recommends local private organizations should give more in-depth look on their feedback session of performance appraisal system.

\section{References:}

Ahmad, R. and Spice, D.P. (2000). "Practice of performance appraisal in the Malaysian public service: Proposal for research exploring the cognitive processing model". Paper presented at the First Symposium on Graduate Management Research, Universiti Utara Malaysia, Kedah Darul Aman, 15-16 November.

Akhter, N. (2008). Performance Appraisal of the Employees of Local Private Manufacturing Enterprises in Bangladesh. Business Review, (Khulna University Journal of Business Studies), 06(1): 75-82.

Argyris, C. (1994). Good Communication that Block Learning. Harvard Business Review, 72(4): 77-85.

Armstrong, M. (1998). Managing people: A Practical Guide for Line Managers, London: Kogan Page.

Armstrong, M. and Baron, A. (1998). Performance Management: The New Realistic, London: Institute of Personnel and Development.

Ashford, S. J. (1986). Feedback Seeking in Individual Adaptation-A Resource Perspective. Academy of Management Journal, 29 (3): 465-487. 
Bartol, K. M. and Locke, E. A. (2000). Incentives and Motivation. In Sara L. Rynes and Barry Gerhart (Eds.), Compensation in Organizations: Current Research and Practice (104-147). San Francisco: Jossey Bass.

Bratton, J. and Gold, J. (1999). Human Resource Management: Theory and Practice (2nd Ed) London: Macmillan Business.

Beach, D. S. (1995). Personnel: The Management of People at Work. New York.

Borman, W. C. (1979). Format and training effects on rating accuracy and rater errors. Journal of Applied Psychology, 64: 412-421.

Butler J., Ferris G. and Nappier N. (1991). Strategy and Human Resource Management. Cincinnati, OH: South- Western Publishing Co.

Carroll, S. J. and Schneier, E. C. (1982). Performance Appraisal and Review Systems: The Identification. Measurement and Development of Performance in Organizations. Glenview, IL: Scott, Foresman.

Cascio, W. \& Baeley, E. (1995). International Human Resource Management. The state of research and practice. In O. Shekar (Ed.) Global Perspective of Human Resource Management. (16-36), Prentice hall: Englewood cliffs, N. J.

Festinger, L. (1954). A Theory of Social Comparison Process. Human Relations, 7(2): 117-40.

Fisher, C. D., Schoenfeldt, L. F. and Shaw, J. B. (2008). Human Resource Management (Fifth Edition). Indian Adaptation.

Hillery, J. M. and Wexely, K. N. (1974). Participation in Appraisal Interviews Conducted in a Training Situation. Journal of Applied Psychology, 59: 168-171.

Ilgen, D. P., Petersen, R. B., Martin, B. A. and Boeshen, B. A. (1981). Supervisor and subordinate reactions to performance appraisal sessions. Organizational Behavior and Human Performance. 28: 311-330.

Kluger, Abraham N. and Angelo De Nisi. (1996) "The Effects of Feedback Interventions on Performance: A Historical Review, Meta- Analysis and a Preliminary Feedback Intervention Theory. Psychological Bulletin, 119: 254-84.

Landy, F. J., Barnes, J. L. and Murphy, K. R. (1978). Correlates of Perceived Fairness and Accuracy of Performance Evaluation. Journal of Applied Psychology, 63: 751-754.

Landy , F. J. and Farr, J. L. (1980). Performance Rating. Psychological Bulletin, 87: 72-107.

Latham G.. P. and Wexley, K. N. (1981). Increasing Productivity through Performance Appraisal, Addison Wesley, Inc.

Larson, J. R. (1984).The Performance Feedback Process: A Preliminary Model. Organizational Behavior and Human Performance, 33(February): 42-76.

Lawler, E. E. (1994). Motivation in Work Organizations. San Francisco: Jossey-Bass.

Milliman, J. F., Nathan, B., \& Mohrman, A. M. (1991). Conflicting Appraisals Purposes of Managers and Subordinates and their Effect on Performance and Satisfaction. Paper presented at the Academy of Management Meeting. Miami, FL.

Millward, N., Bryson, A. and Forth, J. (2000). All Change at Work? British employment relations 1980-1998, as portrayed by the Workplace Industrial Relations Survey, London: Routledge.

Nadler, D. A. (1977). Feedback and Organizational Development: Using Data Based Methods. Reading, MA: Addison-Wesley.

Perry, J. (1995). Compensation, Merit pay and Motivation, in Hays, S.W. and Kearney, R.C. (Eds) Public Personnel Administration: Problems and Prospects, Prentice Hall, Englewood Cliffs, NJ.

Saal, F. E., Downey, R. G. and Lahey, M. A. (1980). Rating the ratings: assessing the psychometric quality of rating data. Psychological Bulletin, 88: 413-428. 
Taylor, Susan M., Cynthia D. Fisher and Daniel R Ilgen. (1984). Individuals' Reaction to Performance Feedback in Organizations: A Control theory Perspective. In Kenneth M. Rowland and Gerald R. Ferris, eds. Research in Personnel and Human Resource Management. Greenwich, CT: JAI Press.

Vroom, V. H. (1964). Work and Motivation. New York: Wiley.

Wilson, J. P. and Western, S. (2000). Performance Appraisal: An Obstacle to Training and Development? Performance Journal of European Industrial Training, 24(7): 384-390.

Yong, A. K. B. (1996). Malaysian Human Resource Management. Malaysian Institute of Management, Kuala Lumpur.

Yousef, D. (2000). Employees' Perceptions of Performance Appraisal System and Their Relationships with Some Personal and Organizational Factors: An Empirical Study in the Organizations in the United Arab Emirates. Public Administration, Riyadh, 40(3): 575-608. 